\title{
Analisis Following to Follower Instagram pada 6 Brand Sepatu Lokal dengan Kualitas Bagus dan Harga Terjangkau
}

\author{
Tri Cahyo Gusmantoro \\ gusman.tricahyo@gmail.com
}

\begin{abstract}
Instagram is a social media application developed by Facebook. Instagram is a place to convey messages through creative photos and videos. Users can take photos and/or videos, edit them with various tools and filters, then upload them at once on this most popular social media. The Instagram application can also be used as an opportunity for brands or companies as a social media marketing platform because Instagram has a positive and significant effect on buying or shopping interest. So with this, Instagram is able to provide very high opportunities for companies in doing digital marketing. There are 6 local shoe brands that use Instagram as a marketing platform, namely: Ventela Shoes, Aerostreet, Wakai Indonesia, Eagle Shoes, Footstep Footwear, and Tomkins Indonesia. The purpose of this study is to calculate the credibility of the Instagram account performance of the 6 Local Shoe Brands. The method used for this research is quantitative exploratory method. The results of this study indicate that the Tomkins Indonesia brand is ranked first and has good account performance credibility.
\end{abstract}

\begin{abstract}
ABSTRAK
Instagram merupakan aplikasi sosial media yang diluncurkan oleh Facebook. Instagram menjadi tempat untuk menyampaikan pesan melalui foto dan video yang kreatif. Pengguna bisa mengambil foto dan/atau video, mengeditnya dengan berbagai tools dan filter, lalu mengunggahnya sekaligus di sosial media terpopuler ini. Aplikasi Instagram juga dapat dijadikan peluang bagi brand atau perusahaan sebagai platform social media marketing dikarenakan Instagram berpengaruh positif dan signifikan terhadap minat beli atau berbelanja. Sehingga dengan ini, Instagram mampu memberikan peluang yang sangat tinggi bagi perusahaan-perusahaan dalam melakukan digital marketing. Adapun 6 Brand Sepatu Lokal yang memanfaatkan Instagram sebagai platform marketing, yaitu : Ventela Shoes, Aerostreet, Wakai Indonesia, Eagle Shoes, Footstep Footwear, dan Tomkins Indonesia. Tujuan dari penelitian ini yaitu untuk menghitung kredibilitas dari performa akun Instagram 6 Brand Sepatu Lokal tersebut. Metode yang digunakan untuk penelitian ini yaitu metode eksploratif kuantitatif. Hasil dari penelitian ini menunjukkan bahwa brand Tomkins Indonesia mendapatkan peringkat pertama dan memiliki kredibilitas performa akun yang baik.
\end{abstract}

Keyword : Credibility Account Instagram ; Social Media Marketing ; Social Media Instagram; Followers to Following Ratio ; Sepatu Lokal. 


\section{PENDAHULUAN}

Teknologi informasi dan komunikasi yang telah berkembang dengan pesat mampu menghantarkan manusia untuk menciptakan bentuk baru dalam cara berkomunikasi serta berinteraksi melalui media sosial. Media sosial memberikan pengaruh yang cukup besar, saat ini media sosial dijadikan sarana berkomunikasi dalam setiap aktivitas keseharian bersosial di masyarakat. Komunikasi tidak hanya dapat dilakukan secara fisik, tetapi juga dapat dilakukan dengan menggunakan berbagai aplikasi media sosial di dunia maya. Keunggulan layanan aplikasi sosial media adalah memberikan ruang komunikasi dua arah antara konsumenperusahaan dan konsumen-konsumen.

Dengan pesatnya perkembangan teknologi media sosial, telah memberikan dampak terhadap situs-situs komunikasi, dari yang awalnya hanya sekedar email dan chatting, saat ini sudah banyak jejaring media sosial yang bisa digunakan sebagai alat komunikasi. Contoh aplikasi sosial media yang memiliki banyak pengguna saat ini yaitu Instagram. Nama Instagram berasal dari pengertian dari keseluruhan fungsi aplikasi ini. Kata "insta" berasal dari kata "instan", seperti kamera polaroid yang pada masanya lebih dikenal dengan sebutan "foto instan". Instagram juga dapat menampilkan foto-foto secara instan, seperti polaroid di dalam tampilannya. Sedangkan untuk kata "gram" berasal dari kata "telegram", dimana cara kerja telegram sendiri adalah untuk mengirimkan informasi kepada orang lain dengan cepat (Agustinna, Purnama, and Abdurrahman 2017).

Instagram sebagai sebuah media baru tentunya membawa banyak perubahan pada kehidupan masyarakat. Lewat instgram, perkembangan online shop menjadi sangat pesat. Instagram secara tidak langsung menjadi media iklan yang cukup efektif untuk memasarkan suatu produk baru (Agustinna, Purnama, and Abdurrahman 2017). Hal ini tentunya memberikan peluang bagi brand untuk menjadikan platform ini sebagai platform social media marketing. Cukup banyak akun perusahaan-perusahaan terkenal yang ada pada instagram, contohnya seperti 6 brand sepatu lokal. Adapun 6 brand sepatu lokal tersebut, yaitu : Ventela Shoes, Aerostreet, Wakai Indonesia, Eagle Shoes, Footstep Footwear dan Tomkins Indonesia (Halidi and Rachmawati 2021).

Penelitian ini menggunakan metode eksploratif kuantitatif, dan akan menghitung menggunakan rasio-rasio yang ada pada Instagram. Pada penelitian (Hendika Permana 2021) menjelaskan bahwa terdapat 14 rasio yang ada pada sosial media Instagram dan relevan digunakan sebagai media ukur kredibilitas akun yang ada. Penelitian ini hanya berfokus untuk menghitung kredibilitas Following to Followers Ratio pada 6 Brand Sepatu Lokal. Tujuan dari penelitian ini adalah mengetahui kredibilitas performa dari akun Instagram 6 Brand Sepatu Lokal menggunakan Following to Followers.

\section{TINJAUAN PUSTAKA}

Perkembangan bidang teknologi saat ini terjadi begitu pesat. Melalui perkembangan yang terjadi dari waktu ke waktu menimbulkan maraknya aplikasi - aplikasi serta platform media sosial yang bermunculan. Aplikasi yang sangat diminati oleh masyarakat saat ini diantaranya adalah TikTok, Instagram, Twitter, WhatsApp dan yang lain sebagainya. Seiring berjalannya waktu, aplikasi sosial media tersebut dapat menjadi candu bagi kalangan masyarakat. Tidak hanya kalangan remaja yang menggunakan aplikasi sosial media, orang tua bahkan anak-anak juga aktif menggunakan aplikasi sosial media tersebut.

Berdasarkan penelitian We Are Social 2020, Instagram merupakan platform visual terbesar saat ini. Instagram menjadi tempat untuk menyampaikan pesan melalui foto dan video yang kreatif. 
Pengguna bisa mengambil foto dan/atau video, mengeditnya dengan berbagai tools dan filter, lalu mengunggahnya sekaligus di sosial media terpopuler ini. Instagram juga memiliki fitur Instagram Story yang mudah digunakan untuk menangkap momen dalam video singkat (Reinaldi 2021).

Di Indonesia, fenomena anak muda dalam menggunakan Instagram menunjukkan antusiasme yang sangat masif. Jumlah pengguna Instagram di Indonesia tahun 2020 adalah 63 juta jiwa atau $79 \%$ dari jumlah populasi. Dengan persentase pengguna Instagram berjenis kelamin perempuan yaitu 50,8\% dan persentase pengguna Instagram berjenis kelamin laki-laki: 49,2\% (Andi Dwi Riyanto 2020).

Aplikasi Instagram tidak hanya digunakan untuk membuat konten foto dan video dengan tujuan menghibur pengguna lainnya. Aplikasi Instagram juga dapat dijadikan peluang bagi brand atau perusahaan sebagai platform social media marketing. Penelitian (Adenia 2019) menyatakan bahwa Instagram berpengaruh positif dan signifikan terhadap minat beli atau berbelanja. Sehingga dengan ini, Instagram mampu memberikan peluang yang sangat tinggi bagi perusahaan-perusahaan dalam melakukan digital marketing.

Instagram dirasakan memiliki kekuatan ataupun pengaruh dalam industri, sehingga menimbulkan kualitas akun yang menentukan strata maupun kredibilitas pemilik akun. Kredibilitas akun Instagram merupakan suatu hal yang cukup penting untuk berbagai kepentingan. Kredibilitas sebuah akun Instagram dapat diukur dari tingkat performa yang dihasilkan secara matematis. Dalam mengukur performa diperlukan skala pengukuran yang tertuang ke dalam rasio.

\section{METODE PENELITIAN}

Penelitian ini menggunakan metode eksploratif kuantitatif untuk mengetahui kredibilitas dari performa akun Instagram dari 6 Brand Sepatu Lokal dengan Kualitas Bagus dan Harga Terjangkau. Penelitian eksploratif bersifat kreatif, fleksibel dan terbuka, dimana dalam penelitian ini semua sumber dianggap penting untuk dijadikan sumber informasi (Mudjiyanto 2018).

Tujuan dari penelitian ini adalah mengetahui nilai kredibilitas dari performa akun Instagram dari 6 Brand Sepatu Lokal dengan Kualitas Bagus dan Harga Terjangkau. Dalam penelitian ini, ada beberapa langkah yang harus dilakukan sehingga peneliti dapat menyimpulkan peringkat pertama akun Instagram dari 6 Brand Sepatu Lokal yang memiliki performa terbaik. Langkahlangkah yang dilakukan pada penelitian ini, diantaranya yaitu:

\section{Melakukan Eksplorasi dan Mencari Informasi Untuk Menentukan Objek yang} Akan Dianalisa.

Eksplorasi dan pencarian informasi ini dilakukan pada beberapa halaman website yang menyediakan informasi mengenai objek yang akan di teliti. Setelah pencarian informasi selesai dilakukan, ditemukan nama-nama brand sepatu lokal Indonesia yang akan dijadikan objek analisa. Setelah melakukan pencarian informasi pada halaman website, maka langkah selanjutnya yaitu mencari nama akun Instagram dari masing-masing brand sepatu lokal tersebut. 


\section{Mencari Nilai Masing - Masing Variable dari 6 Brand Sepatu Lokal}

Pada langkah ini peneliti mengumpulkan nilai variabel following dan follower pada setiap akun Instagram 6 Brand Sepatu Lokal Tersebut. Variabel merupakan sesuatu yang memiliki nilai bervariasi dimana nilai tersebut dapat dijadikan sebagai dasar untuk empat data yang berbeda seperti rasio, skala, ordinal, nominal dan internal (Rankuti 2015). Untuk mengumpulkan nilai variabel dari following dan follower yaitu dengan cara membuka halaman utama dari setiap akun Instagram 6 Brand Sepatu Lokal Tersebut.

\section{Menghitung Nilai Kredibilitas Ratio}

Untuk menghitung nilai kredibilitas dari following to follower ratio, peneliti menggunakan cara membagi nilai variabel following dengan nilai variabel follower. Jika following memiliki nilai 10 dan follower memiliki nilai 1000, maka cara menghitungnya yaitu $10: 1000=0,01$. Dengan begitu nilai dari following to follower ratio adalah 0,01 .

\section{Menentukan Peringkat Pada Akun Instagram}

Langkah terakhir yang dilakukan pada penelitian ini yaitu menentukan peringkat pada masing-masing nilai rasio yang dimiliki oleh setiap akun. Untuk menentukan peringkat ini perlu melihat karakteristik dari rasio yang di teliti. Jika karakteristik rasio merupakan rendah, maka objek yang memiliki nilai rasio paling rendah akan mendapatkan angka 6 dan objek yang memiliki nilai rasio paling tinggi akan mendapatkan angka 1. Namun jika rasio memiliki karakteristik tinggi maka objek yang mendapatkan nilai rasio paling tinggi akan mendapatkan angka 5 dan objek yang mendapatkan nilai rasio paling rendah akan mendapatkan angka 1. Setelah mendapatkan hasil kredibilitas rasio maka dapat disimpulkan objek yang mana mendapatkan peringkat 1 sampai dengan peringkat 6 .

\section{HASIL DAN PEMBAHASAN}

Akun Instagram dari 6 Brand Sepatu Lokal dengan Kualitas Bagus dan Harga Terjangkau, diantaranya :

\section{Ventela Shoes}

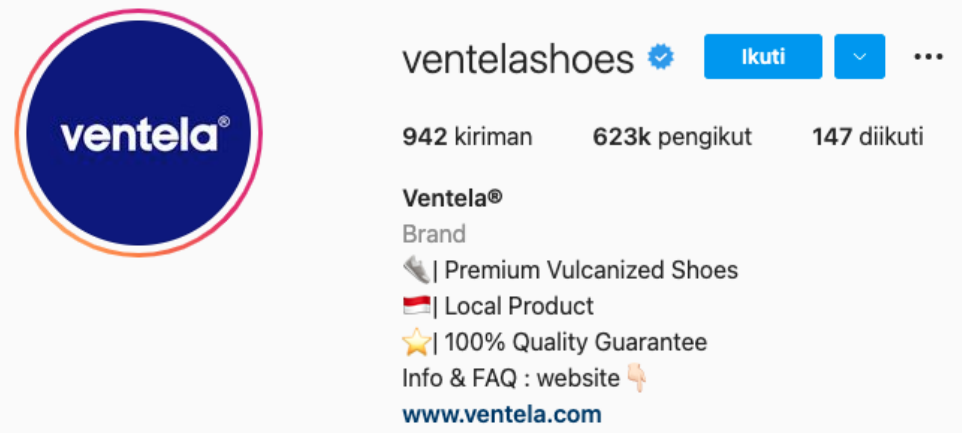

Gambar 1. Akun Instagram Ventela Shoes

Sumber : https://www.instagram.com/ventelashoes/?hl=id (akses pada 20-10-2021) 


\section{Aerostreet}
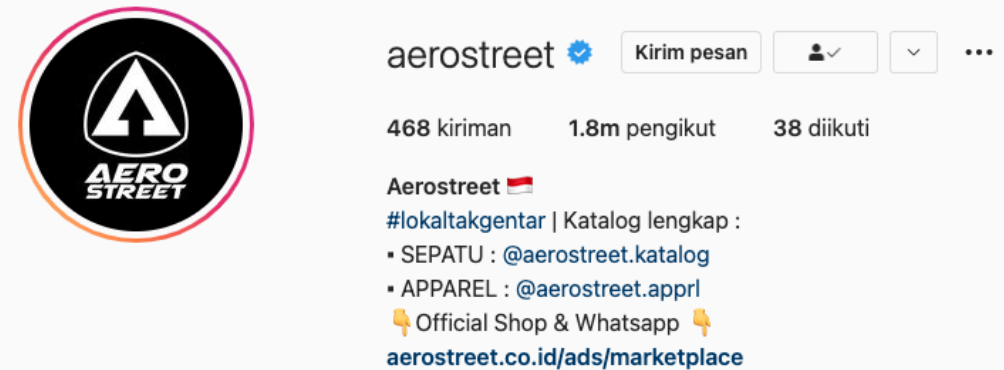

Gambar 2. Akun Instagram Aerostreet

Sumber : https://www.instagram.com/aerostreet/?hl=id (akses pada 20-10-2021)

\section{Wakai Indonesia}

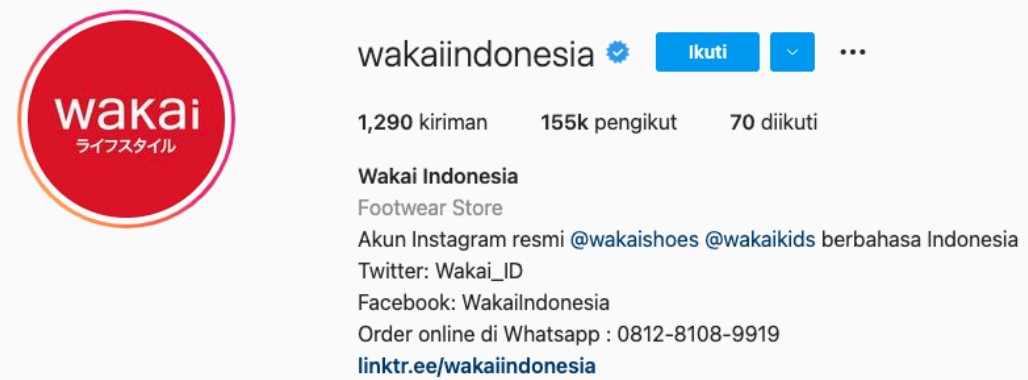

Gambar 3. Akun Instagram Wakai Indonesia

Sumber : https://www.instagram.com/wakaiindonesia/?hl=id (akses pada 20-10-2021)

\section{Eagle Shoes}

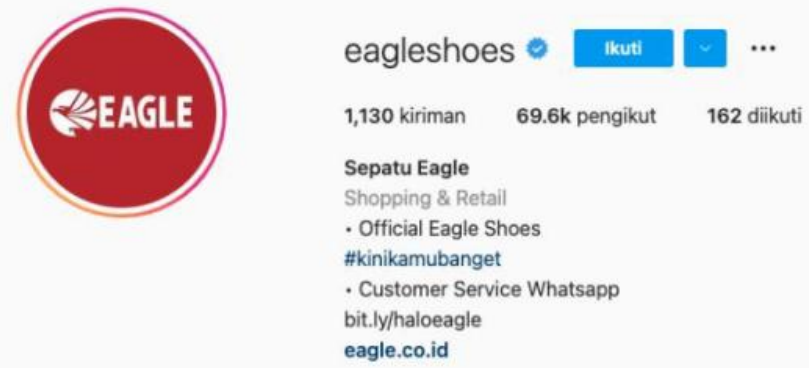

Gambar 4. Akun Instagram Eagle Shoes

Sumber : https://www.instagram.com/eagleshoes/?hl=id (akses pada 20-10-2021)

\section{Footstep Footwear}

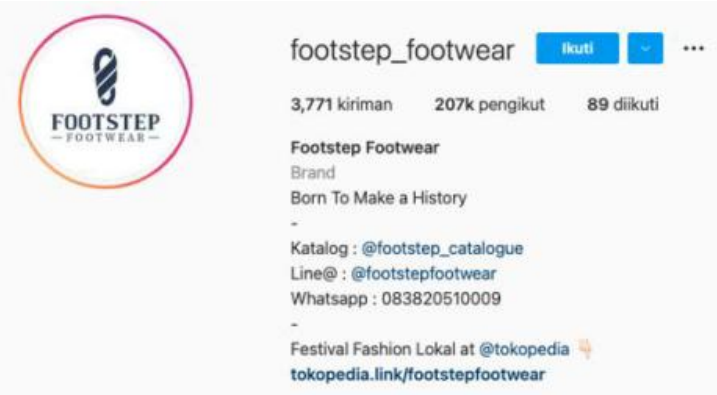

Gambar 5. Akun Instagram Footstep Footwear

Sumber : https://www.instagram.com/footstep_footwear/?hl=id (akses pada 20-10-2021) 


\section{Tomkins Indonesia}

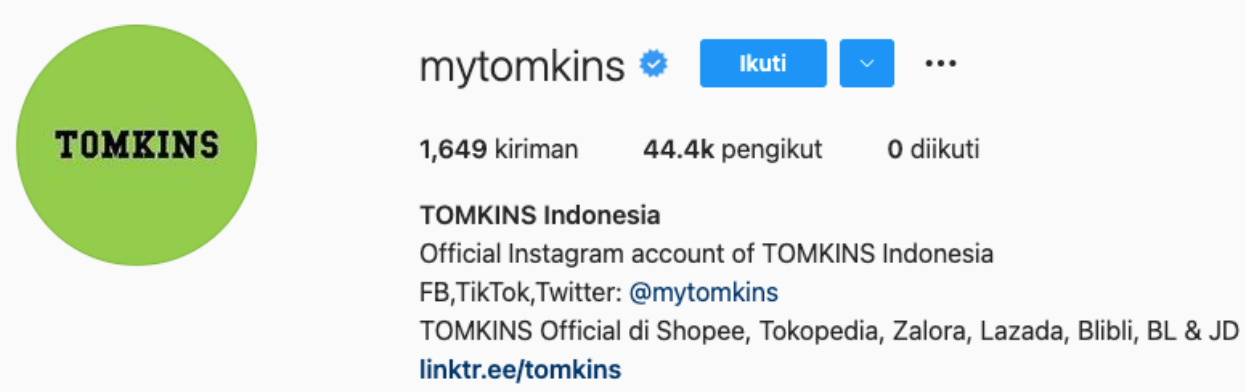

Gambar 6. Akun Instagram Tomkins Indonesia

Sumber : https://www.instagram.com/mytomkins/?hl=id (akses pada 20-10-2021)

Dari keenam akun Instragram 6 Brand Sepatu Lokal dengan Kualitas Bagus dan Harga Terjangkau, peneliti menemukan nilai dari masing-masing variabel yang ada untuk menghitung rasio Following to Followers dari setiap akun. Pada akun Instagram terdapat 8 variabel, diantaranya yaitu :

1. Post

2. Followers

3. Following

4. Image Likes

5. Image Comments

6. Video Views

7. Video Likes

8. Video Comments

Dari kedelapan variabel tersebut peneliti hanya fokus untuk menemukan hasil dari 2 variabel, yaitu :

1. Following

2. Followers

Berikut ini merupakan nilai dari variabel Following dan Followers yang peneliti dapatkan

Tabel 1. Nilai Variabel Pada Instragram 6 Brand Sepatu Lokal dengan Kualitas Bagus dan Harga Terjangkau

\begin{tabular}{|l|c|c|}
\hline \multirow{2}{*}{ Brand } & \multicolumn{2}{c|}{ Variabel } \\
\cline { 2 - 3 } & Following & Followers \\
\hline Ventela Shoes & 147 & 62300 \\
\hline Aerostreet & 38 & 1800000 \\
\hline Wakai Indonesia & 70 & 155000 \\
\hline Eagle Shoes & 162 & 69600 \\
\hline Footstep Footwear & 89 & 207000 \\
\hline Tomkins Indonesia & 0 & 44400 \\
\hline
\end{tabular}

Sumber : Pengolah Data Excel 
Pada akun Instagram terdapat 14 rasio yang relevan digunakan untuk mengukur kredibilitas pada masing-masing akun. Namun pada penelitian kali ini hanya berfokus untuk menghitung Following to Followers Ratio. Untuk menghitung kredibilitas dari masing-masing akun Instagram setiap brand sepatu lokal, peneliti menghitung dengan cara : variabel 1 akan dibagi dengan variabel 2, sehingga ditemukan hasil analisis dari rasio tersebut.

Tabel 2. Hasil Perhitungan Rasio Akun Instagram

\begin{tabular}{|c|l|r|}
\hline No & \multicolumn{1}{|c|}{ Object } & \multicolumn{1}{c|}{ Nilai Ratio } \\
\hline 1 & Ventela Shoes & 0,00023596 \\
\hline 2 & Aerostreet & 0,00002111 \\
\hline 3 & Wakai Indonesia & 0,00045161 \\
\hline 4 & Eagle Shoes & 0,00232759 \\
\hline 5 & Footstep Footwear & 0,00042995 \\
\hline 6 & Tomkins Indonesia & 0,00000000 \\
\hline \multicolumn{2}{|c|}{ Sumber : Pengolah Data Excel } \\
\hline
\end{tabular}

Following to Followers ratio memiliki karakteristik yang rendah, artinya semakin rendah nilai yang dihasilkan maka semakin baik kredibilitas dari performa akun tersebut. Untuk memberikan peringkat pada masing-masing Brand Sepatu Lokal, peneliti memberikan angka 6 kepada brand yang mendapatkan nilai tertinggi dan angka 1 untuk brand sepatu yang mendapatkan nilai terendah. Berikut merupakan tabel urutan nilai yang dihasilkan oleh masingmasing brand sepatu lokal.

Tabel 3. Nilai Rasio Akun Instagram 6 Brand Sepatu Lokal dengan Kualitas Bagus dan Harga Terjangkau

\begin{tabular}{|l|c|}
\hline \multicolumn{1}{|c|}{ Brand } & Nilai Following to Followers Ratio \\
\hline Ventela Shoes & 4 \\
\hline Aerostreet & 5 \\
\hline Wakai Indonesia & 2 \\
\hline Eagle Shoes & 1 \\
\hline Footstep Footwear & 3 \\
\hline Tomkins Indonesia & 6 \\
\hline
\end{tabular}

Sumber : Pengolah Data Excel

Dari Tabel Nilai Rasio Akun Instagram 6 Brand Sepatu Lokal dengan Kualitas Bagus dan Harga Terjangkau dapat simpulkan bahwa Tomkins Indonesia mendapatkan nilai tertinggi untuk rasio Following to Followers. Sedangkan akun Instagram Eagle Shoes mendapatkan nilai terendah untuk rasio ini. Jadi, pada penelitian ini Tomkins Indonesia memiliki kredibilitas performa yang lebih baik dibandingkan dengan brand sepatu lokal yang lainnya.

\section{KESIMPULAN}

Tujuan dari penelitian ini adalah mengetahui kredibilitas performa dari akun Instagram 6 Brand Sepatu Lokal dengan Kualitas Bagus dan Harga Terjangkau menggunakan Following to Followers Ratio. 6 Brand Sepatu Lokal tersebut diantaranya : Ventela Shoes, Aerostreet, Wakai 
Indonesia, Eagle Shoes, Footstep Footwear, dan Tomkins Indonesia. Dari keenam brand sepatu lokal tersebut dapat disimpulkan bahwa :

1. Peringkat pertama diraih oleh brand Tomkin Indonesia dengan nilai tertinggi yaitu 0,00000000

2. Peringkat kedua diraih oleh brand Aerostreet dengan nilai 0,00002111

3. Peringkat ketiga diraih oleh brand Ventela Shoes dengan nilai 0,00023596

4. Peringkat keempat diraih oleh brand Footstep Footwear dengan nilai 0,00042995

5. Peringkat kelima diraih oleh brand Wakai Indonesia dengan nilai 0,00045161

6. Peringkat terakhir diaih oleh brand Eagle Shoes dengan nilai terendah yaitu 0,00232759 


\section{DAFTAR PUSTAKA}

Adenia, Nia. 2019. Pengaruh Media Sosial Instagram Terhadap Minat Beli Konsumen Secara

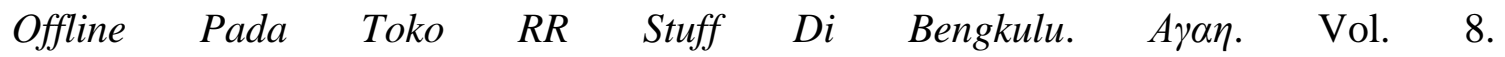
http://repository.iainbengkulu.ac.id/3482/1/NIA ADENIA.pdf.

Agustinna, Kartika, Hadi Purnama, and Muhammad Sufyan Abdurrahman. 2017. "Kata Kunci: Personal Branding, Instagram, Selebgram Keywords: Personal Branding, Instagram , Selebgram." Analisis Strategi Personal Branding Melalui Media Sosial $\begin{array}{llr}\text { Instagram } & 4 & (1):\end{array}$ https://openlibrary.telkomuniversity.ac.id/pustaka/files/123913/jurnal_eproc/strategipersonal-branding-selebgram-melalui-media-sosial-instagram.pdf.

Andi Dwi Riyanto. 2020. "Hootsuite (We Are Social): Indonesian Digital Report 2020.” 2020. https://andi.link/hootsuite-we-are-social-indonesian-digital-report-2020/.

Halidi, Risna, and Dinda Rachmawati. 2021. "6 Brand Sepatu Lokal Dengan Kualitas Bagus Dan Harga Terjangkau.” June 2021. https://www.suara.com/lifestyle/2021/06/14/110142/6-brand-sepatu-lokal-dengankualitas-bagus-dan-harga-terjangkau-mana-favoritmu?page=all.

Hendika Permana, I Putu. 2021. "Analisis Rasio Pada Instagram Untuk Penelitian Kualitatif Menggunakan Metode Ekploratif." Jurnal Ilmiah Media Sisfo 15 (1): 40. https://doi.org/10.33173/jsikti.109.

Mudjiyanto, Bambang. 2018. “Tipe Penelitian Eksploratif Komunikasi." Jurnal Studi Komunikasi Dan Media 22 (1): 65. https://doi.org/10.31445/jskm.2018.220105.

Rankuti, Freddy. 2015. "Buku Riset Pemasaran.” 2015.

Reinaldi, Helmi. 2021. "10 Aplikasi Media Sosial Terpopuler Di Dunia, Paling Banyak Digunakan!” July 1, 2021. https://telset.id/apps/aplikasi-media-sosial-populer/. 